\title{
KOULUTUS JA ELÄMÄNKULKU
}

\section{- Dale Danneferin haastattelu}

Dale Dannefer on sosiologian ja kasvatustieteen apulaisprofessori Rochesterin yliopistossa ja Sociology of Education -aikakauskirjan varapäätoimittaja. Hän puhuu marraskuussa (22.-24.11.) Tampereella järjestettävillä kasvatustieteen päivillä aiheesta 'Homogeneity vs. Heterogeneity: Structural and Developmental Perspectives on Lifelong Learning".

Julkaisemamme haastattelu muodostuu otteista Ari Antikaisen kesäkuussa 1989 tekemästä laajemmasta haastattelusta.

Olet tehnyt väitöskirjasi vanhojen autojen keräilijöistä. Mistä sait moisen aiheen?

Peter Berger oli ensisijainen henkilö, jonka kanssa työskentelin tuohon aikaan. Hän oli kiinnostunut - kuten myös minä - yksityisen elämänalueen (the private sphere) analyysista: mitä ihmiset tekevät yksityiselämässään urbaanissa yhteiskunnassa, jossa yhteisön siteet eivät luonnostaan vaikuta jokapäiväisessä elämänkulussa. Olin kiinnostunut siitä, mikä vaikuttaa sellaiseen toimintaan kuin vanhojen autojen keräily; miksi ihmiset tekevät sitä.

Sovinnainen, jähmeä ja funktionalistinen amerikkalainen sosiologia vakuutti olevan kaksi syytä, minkä vuoksi ihmiset tekevät jotain sellaista, kuin keräävät vanhoja autoja. Ensiksi he tekevät sitä, koska heidän ystävänsäkin tekevät samoin; kysymyksessä olisi siis viitekehyshypoteesi. Toiseksi he tekevät sitä siksi, että heidät on sosiaalistettu siihen vanhempiensa toimesta.

Ajattelin, etteivät nämä syyt olleet todella päteviä tai oikeita. Tiesin kokemuksesta, että oli paljon keräilijöitä, joiden ystävät eivät keräilleet vanhoja autoja ja joiden vanhemmat sekä aviopuolisot kielsivät autojen keräilyn.

Yksi tutkimuksessani luullakseni toteennäyttämä tekijä oli se, että on olemassa todellista subjektiivista voimaa, joka ohjaa ihmisiä tällaiseen keräilyyn tai muuhun yksilölliseen vapaa-ajantoimintoon. Siten kysymys voisi kuulua: Kuka tekee niin, koska kaikki eivät tee niin? Kuka on siihen altis?
Yleinen hypoteesini oli, että läheisten sosiaalisten siteiden puute tai tarpeellisten sosiaalisten suhteiden puuttuminen jättää yksilön enemmän mainosten ja massakulttuurin tuottamien mielikuvien armoille. Sain selville ainakin yhden hypoteesia tukevan seikan: autojen keräilijät olivat hyvin usein perheen ainoita lapsia. Tämä on hyvin karkea indikaattori. Mutta ehkä se tarkoittaa, että heillä oli vähemmän sosiaalista vuorovaikutusta varhaisvuosinaan.

Miten suuntauduit elämänkulun ja aikuisiän kehityksen tutkimukseen?

Halusin jatkaa subjektivisaation tutkimista. Matilda Riveyllä oli parin sadan opiskelijan haastattelut ja päiväkirjat 1950-luvulta. Ajattelin, että toistaisin tutkimuksen 1970-luvun lopulla ja siten tutkisin, miten ihmiset viettivät vapaa-aikaansa 50-luvulla ja nyt. Sitä varten aloin tarkastella aikuisten kehitystä ja elämänkulkua (life course) käsittelevää kirjallisuutta Yalessa oloni aikana.

Dan Levinsonin kirja "'The Seasons of Man's Life" julkaistiin, ja Levinson oli Yalessa. Hän oli kiireinen mies, mutta ystävällinen ja auttavainen. Tapasin hänet kaksi tai kolme kertaa, jolloin keskustelimme hänen kirjastaan. Se mitä luin - Levinsonia ja monia muita elämänkaaren tutkijoita - oli niin väärinjäsennettyä, niin reduktionalistista ja niin universalistisen paradigman hallitsemaa, että jätin empiirisen tutkimuksen ja paneuduin teoriaan. Näin siis tulin kuvioihin mukaan ja aloin kirjoittaa näitä kriittisiä artikkeleita alan teorioista ja sitä samaa teen vielä nytkin. 
Dannerfer katsoo saaneensa vaikutteita monelta suunnalta (kriittinen teoria, marxismi, symbolinen interaktionismi, Giddens, Habermas, Philip Wexler), mutta aina hän keskustelussa palaa opettajaansa Peter Bergeriin. Etsimällä puheesta löytyy myös kritiikkiä, kuten seuraava ote osoittaa:

Olen työskennellyt Peter Bergerin kanssa ja siten sisäistänyt hänen ideoitaan. Mielestäni Berger on todellisuudessa hienostunut funktionalisti. Hän nostaa esiin kysymyksiä koskien tietoa ja legitimaatiota. Hän käy läpi näitä asioita. Mutta hän ei mene eräänlaista konsensuksen rakentamista pidemmälle. Hän ei problematisoi sosiaalista järjestystä. On kuitenkin muistettava, että Bergerin lähtökohta sosiaalisesta todellisuudesta konstruoituna voi avata ihmisten mielet ja silmät inhimilliseen moninaisuuteen ja moniin mahdollisuuksiin - näkemään maailman avoinna inhimilliselle organismille ja sosiaalisten suhteiden muutettavuudelle.

\section{Mitä pidät tärkeimpänä kontribuutionasi} elämänkulun tutkimuksessa?

Luulen, että kuka muu tahansa kuin minä sanoisi vuoden 1984 kirjoituksen Adult Development and Social Theory. Monet ovat lukeneet sen ja sanovat sitä hyväksi. Minusta tuo artikkeli oli pikemminkin valitus. Se oli kuin ensimmäinen askel viiden askeleen projektissa. Nyt myös toinen askel on täydentynyt varsin paljon, ja se on mielestäni paljon tärkeämpi. Sen on määrä yrittää selvittää yksilön vanheneminen sosiaalista dynamiikkaa. Se on tutkimus vanhenemisen moninaisuudesta.

En ole kiinnostunut moninaisuudesta moninaisuuden tähden, vaan koska se pakottaa ihmiset sanomaan, että jotakin on tapahtumassa tavallisen vanhenemisen ohella. Tarkoitukseni on osoittaa, että vanheneminen on jotakin, joka tapahtuu ihmisten välillä, ikäryhmien keskuudessa etenkin iän mukaan jäsentyneissä yhteiskunnissa.

Ensimmäiseltä koululuokalta alkaen ja jopa aikaisemminkin lapsia arvioidaan ja verrataan tavalla, joka vaikuttaa läpi heidän loppuelämänsä. Yritän ymmärtää keski-ikää ja myöhäiskeski-ikää eriytymisprosessina, joka perustuu tämäntyyppiseen sosiaaliseen ryhmittelyyn ja luokitteluun ja itsensä toteuttaviin ennusteisin.

Mainitsen koulun valaisevana esimerkkinä, koska se on niin havainnollinen ja tuttu. Olemme paljolti avoimen interaktiivisia olentoja ja nuo sosiaaliset dynamiikat muuttavat meidän elämänolojamme, työkokemuksiamme ja mahdollisuuksiamme. Ne muokkaavat jotkut meistä "fiksuimmiksi" ja jotkut tyhmemmiksi, jotkut tavoitellummiksi ja jotkut vähemmän tavoitelluiksi, antavat joillekin paremman pääsyn terveydenhuoltoon ja toisille huonomman jne. Tämä porrastuu hyvin selvästi iän mukana.

Pidän parhaana työnäni tuoretta kriittistä artikkelia siitä, miltä todellinen sosiologinen teoria iästä ja kehityksestä näyttää. Se on teoria, joka ottaa huomioon yksilön vanhenemiseen kuuluvat sosiaaliset prosessit. Yksilön vanheneminen on jotakin, jota voidaan ymmärtää vain yhteydessä ihmisten luokkiin, ikäryhmiin ja kohortteihin.

Seuraavana yritän tarkastella merkityksenantoa eli tutkia minuutta suhteessa ikään ja kehitykseen. Merkityksellä tarkoitan kriittistä näkökulmaa minuuteen suhteessa ikään ja kehitykseen. Tätä ei ole vielä tehty. Omien kriteerieni mukaan ikäheterogeenisuutta (aged heterogeneity) koskevat työni ovat siis kontribuutioni.

Millainen on tutkimuksen taso ja kehityksen kärki elämänkulun ja kehityksen (human development) tutkimuksessa?

$\mathrm{Ne}$ ovat olleet teoreettisesti takapajuisia aloja sosiologisessa tutkimuksessa. Viime vuosina on kuitenkin edistytty tilastollisessa tutkimuksessa: on hienoja tilastoja ja upeita pitkittäisaineistoja, esimerkiksi Glen Elderin työt. Näistä tutkimuksista puuttuu kuitenkin dynaaminen sosiologinen konteksti. Mielestäni artikkeli, jonka kirjoitin yhdessä Marion Perlmutterin (1990) kanssa, edustaa kärkeä muodostettaessa käsitystä inhimillisestä kehityksestä. Sitä ei ole vielä julkaistu. Mutta ihmiset, jotka ovat nähneet sen, ovat pitäneet siitä. Olen hyvin kiinnostunut reaktioista ja siitä, käyttääkö sitä kukaan koskaan.

On toinenkin vanhenemisen tutkimuksen suuntaus, joka on kehityksen kärjessä. Se on biososiaalinen tutkimus. On erittäin jännittävää keksiä ja artikuloida yhteyksistä sosiaalisen kokemuksen ja fysiologisen toiminnan välillä. Yhteydet ovat kahdensuuntaisia. Joissakin asioissa on selvä sosiaalinen tulkinta ja joissakin tulkinta ei ole selvä. Silloin halutaan usein esittää biologinen kausaliteetti - ja se on luultavasti todellisuudessa sosiaalinen. Tämä on tärkeä raja-aita, jossa on tarvetta aktiiviseen varovaisuuteen. On vaara erilaisiin reduktionistisiin tulkintoihin, jotka ottavat pois sosiaalisesta todellisuudesta siihen kuuluvia osia. Tämä on myös tutkimuksen haaste. 
Olemme jo keskustelleet sosialisaatiotutkimuksesta luonnokseni pohjalta. Haluatko sanoa vielä jotakin omasta sosiaalisaatioteoriastasi?

Niin . . mielestäni piilotajunta on todellisuudessa vähäisemmässä määrin peräisin kasvokkaisesta sosiaalisesta vuorovaikutuksesta. Se määräytyy enemmän, kuin termi sosialisaatio osoittaa, inhimillisesti koostuvasta fyysisen maailman sisäistämisestä. Mielestäni inhimillisesti rakentuvassa fyysisessä maailmassa on paljon sellaisia tekijöitä, jotka ovat keskeisiä agentteja sosialisaatiossa. Laskisin niihin mukaan joukkotiedotuksen, mainonnan, julkaisut, artikkelit niissä, television. Edelleen rakennusten ja huonekalujen muoto ja kaikenlaisten teknisten kojeiden muoto. Tajunnassa on tasoja, ja tutkimukseni autoihmisistä sai minut ajattelemaan niitä. Heidän harrastuksensahan perustuu vahvaan tunteeseen, eräänlaiseen intohimoon. Sitä ei ole opittu, siitä ei puhuta ja kuitenkin se perustuu varhaisvuosien sosialisaatioon. Mutta se ei ole sosiaalistunut kanssakäymisen kautta, keskustelemalla tai opettamalla omia lapsia tekemään jotakin. On siten sisäisesti olemassa useita tasoja. Ja ulkoisesti on olemassa useita inhimillisen vuorovaikutuksen ulkopuolisia voimia.

\section{Miten luonnehdit yhteiskunnallista tilan- netta amrikkalaisessa yhteiskunnassa? Elättekö jatkuvuuden, muutoksen vai kriisin aikaa?}

Meillä oli tapana puhua disintegraatiosta tai perustavaa laatua olevasta sosiaalisesta muutoksesta tapahtuvana jossakin toisessa ajassa ja paikassa. Näyttää kuitenkin, että muutos tapahtuu juuri nyt ja olemme ehkä vasta sen alussa. Ajattelen väestöllisiä ja taloudellisia muutoksia, jotka tuottavat suuren joukon vähemmistöryhmiin kuuluvia nuoria ja laajan ikääntyneen valkoisen väestön. Suuri osa nuoria on taloudellisen osallistumisen ulkopuolella ... On olemassa mahdollisuus, että poliittinen legitimaatio kyseenalaistetaan ja väkivalta kasvaa.

Eräästä näkökulmasta voi sanoa, että nuorten väkivalta pitäisi ohjata, ei toisiaan vastaan, vaan eräänlaista valkoista vanhainvaltaa vastaan. Se nimittäin on anastanut laajan määrän sosiaalista ja aineellista hyvää ja tehnyt nuoret tarpeettomiksi. Meillä ei ole selvää tietoisuutta, mihin olemme lasten osalta menossa, sillä yhteiskuntamme on niin aikuisorientoitunut.

On yhtäältä jupit, jotka ovat erittäin narsistisia lapsistaan. Mutta useimmat lapset elävät aineellisesti, emotionaalisesti ja sosiaalisesti puutteessa.
En mielellään jatkaisi onnettomia, monogaamisia avioliittoja, mutta olen vakuuttunut avioeron olevan pahasta lapsille. Syynä ei ehkä ole avioero itsessään, vaan tukimekanismien puute. Se, mikä avioerossa menetetään, on kohtalokasta. Toivon, että kaiken tämän osaisin työstää teoreettisin käsittein. Mutta sitä en ole vielä tehnyt.

Puhutaan paljon jupeista, mutta heitä ei ole enempää kuin viisi prosenttia nuorista. Suurempi ryhmä on juntit (yimmies). On ihmisiä, joilla ei ole varaa mennä naimisiin 28 vuoden ikäisinä; se on kuin palaamista 1800-luvulle. Näin oli sata vuotta sitten.

Haluatko vielä kertoa käsityksiäsi koulutuksen uudistamisesta ja uudistusliikkeestä?

Kouluissa näyttää oleva vastenmielisyyttä standardisoituja testejä kohtaan. Tämä kehitys on tervettä, koska mielestäni opetuksen laadun rappeutuminen johtuu paljolti standardisoidusta testaamisesta. Se on vielä vallitseva käytäntö. Mutta vastustus sitä kohtaan näyttää kasvavan.

Marc Tuckerin, Rochesterissa toimivan kansallisen koulutuksen talouden laitoksen johtajan, sanoma on, että ainoa keino, jolla amerikkalaiset voivat kilpailla, on olla uudistajia. Siispä meidän on valmennettava oppilaat ajattelemaan innovatiivisesti.

Olen samaa mieltä. Se on kuitenkin myytti niin kauan, kuin kansallisilla työmarkkinoilla ei ole juurikaan sijaa uudistajille.

Jos katsomme tilastoja, näyttää siltä kuin työvoiman kasvu olisi suurinta sellaisissa ammateissa kuin vartijan työ, hoitotyö, opettajan työ. Puhun tästä koulutuksen uudistuksen yhteydessä siksi, että minulle keskeinen kysymys on, millaisia opiskelijoita me haluamme tuottaa. Luullakseni tähän ei ole helppoa vastata. Mielestäni haluamme tuottaa opiskelijoita, joilla on mielikuvitusta ajattelussaan ja jotka eivät hevin tee epäinhimillistä työtä. Niin kauan kuin tämä ei ole mahdollista, puhe innovaattoreista on yksinkertisti PR-puhetta. Valitettavasti yhtiöiden johtomiehet eivät tänään edes puhu ajattelun ja mielikuvituksen kehittämisestä. He puhuvat perustaidoista.

\section{Suomennos:}

Hannu Kakriainen ja

Ari Antikainen

Osa haastattelusta tehtiin Chrysler-henkilöautossa vuosimallia 1960. 